УДК 82I.5II.I42.0

ББК $83.3(=667)$

\section{НАЕДИНЕ СО ВСЕМИ: ХУДОЖЕСТВЕННЫЙ МИР ЛЕСНОГО НЕНЦА ЮРИЯ ВЭЛЛЫ}

\author{
(C) 2020 г. А.А. Арзамазов \\ Удмуртский федеральный исследовательский \\ центр Уральского отделения \\ Российской академии наук, \\ Ижевск, Россия \\ Дата поступления статьи: І6 марта 2020 г. \\ Дата публикации: 25 сентября 2020 г. \\ DOI: https://doi.org/IO.22455/2500-4247-2020-5-3-290-307
}

Аннотация: Творчество ненецкого поэта Юрия Вэллы занимает особое местоположение в системе межлитературной общности народов России. С одной стороны, оно вписывается в основные парадигмы развития национальных литератур на рубеже XX-XXI вв. (резкое усиление художественных позиций русского языка в этногуманитарной среде, наличие урбанистического мотивно-образного кластера, актуализированность экологической тематики, репрезентативность социальных нарративов, высокий уровень этнографичности письма и др.). С другой стороны стихи Вэллы - одна из возможных траекторий движения поэтических традиций народов России в ближайшем будущем (увеличение значимости верлибра, повышенное внимание к этнолингвистическому «орнаментированию» текстов, расширение изобразительной составляющей в структуре книги, сосуществование под одной обложкой разных языков). Жизнь и поэзия Юрия Вэллы еще раз подтверждают сентенцию о том, что важнейшим катализатором становления, фактором развития национальной литературы является наличие активной и разносторонней творческой индивидуальности. Рассмотрение особенностей художественного мира Юрия Вэллы представляет интерес в контексте исследования современного состояния национальных литератур народов Крайнего Севера.

Ключевые слова: национальная литература, литературные традиции народов Крайнего Севера, образная символика, жанровая система, художественное многоязычие, экология, урбанистические сюжеты.

Информация об авторе: Алексей Андреевич Арзамазов - доктор филологических наук, ведущий научный сотрудник, Удмуртский федеральный исследовательский центр Уральского отделения Российской академии наук, ул. Ломоносова, д. 4, 426004 г. Ижевск, Удмуртская Республика, Россия. ORCID ID: https://orcid.org/oooo-oooI-7577-59I7

E-mail: arzami@rambler.ru

Для цитирования: Арзамазов А.А. Наедине со всеми: художественный мир лесного ненца Юрия Вэллы // Studia Litterarum. 2020. Т. 5, № 3. С. 290-307. DOI: https://doi.org/Io.22455/2500-4247-2020-5-3-290-307 


\title{
FACE TO FACE WITH EVERYBODY: FICTIONAL WORLD OF THE FOREST NENETS YURI VELLA
}

This is an open access article distributed under the Creative Commons Attribution 4.0 International (CC BY 4.0)

\author{
(C) 2020. A.A. Arzamazov \\ Udmurt Federal Research Center of the Ural Branch \\ of Russian Academy of Sciences, \\ Izhevsk, Russia \\ Received: March I6, 2020 \\ Date of publication: September 25, 2020
}

\begin{abstract}
Creative work of the Nenets poet Yuri Vella occupies a special place in the literary community of the peoples of Russia. On the one hand, it fits into the main paradigms of the development of national literatures at the turn of the $2 \mathrm{O}^{\text {th }}-2 \mathrm{I}^{\text {st }}$ centuries (rapid increase of the dominance of the Russian language in the ethnohumanitarian environment; urbanistic motivic and figurative cluster; the relevance of the environmental topics; representative value of social narratives; a high level of ethnographic writing, etc.). On the other hand, Vella's poems highlight one of the possible trajectories of the poetic traditions of the peoples of Russia in the near future (increased significance of the free verse; increased attention to ethnolinguistic "ornamentation" of texts; expansion of the visual component in the structure of the book; coexistence of different languages under one cover). The life and poetry of Yuri Vella confirm that the most important catalyst for the development of national literature is the author's own active and creative personality. At the same time, the study of Yuri Vella's work has interest in the context of broader studies of the national literature of the peoples of the Far North and its current state.
\end{abstract}

Keywords: national literature, literary traditions of the peoples of the Far North, figurative symbolism, genre system, artistic multilingualism, ecology, urban plots.

Information about the author: Alexey A. Arzamazov, DSc in Philology, Leading Research Fellow, Udmurt Federal Research Center of the Ural Branch of Russian Academy of Sciences, Lomonosov 4, 426004 Izhevsk, Udmurt Republic, Russia.

ORCID ID: https://orcid.org/oooo-oooI-7577-59I7

E-mail: arzami@rambler.ru

For citation: Arzamazov A.A. Face to Face with Everybody: Fictional World of the Forest Nenets Yuri Vella. Studia Litterarum, 2020, vol. 5, no 3, pp. 290-307. (In Russ.) DOI: https://doi.org/I0.22455/2500-4247-2020-5-3-290-307 
Одно из потенциально актуальных направлений современной отечественной филологии - литературоведческие исследования, обращенные к художественным традициям народов России. При этом на сегодняшний день ощущается явный дефицит научных работ систематизирующего характера, рассматривающих национальные литературы в контексте «общего» и «особенного», в системе стадиально-типологических проекций и параллелей. Данный вектор исследований приобретает особую значимость в аспекте моделирования теории «младописьменных» литератур. Среди известных нам трудов продуктивной теоретико-методологической новизной отличаются работы В.Р. Аминевой [г], З.А. Кучуковой, Л.Ф. Хараевой [І4], К.К. Султанова [20; 2г], В.Г. Родионова [18], Ю.Г. Хазанкович [23] и др. Очевидно, что литературы народов России находятся на разных стадиях развития, характеризуются широким спектром внутренних и внешних проблем. Вместе с тем речь может (и должна) идти и об объективных общих механизмах становления, параметрах обновления литературных систем, о разносторонней реальности их сближения. В данной статье в контексте обозначенных выше перспектив исследования осуществляется поиск индивидуально-авторских маркеров, определяющих специфику «движения» литературы конкретной культурно-региональной зоны и/или их перекрестья, предпринимается попытка рассмотрения художественного творчества Юрия Вэллы.

Юрий Кылевич Вэлла (Айваседа) (1948-2013) - один из наиболее интересных и при этом недостаточно оцененных национальных поэтов конца XX - начала XXI вв. Ему, как и другим писателям из народов России, приходилось заниматься многим, осваивать разные профессии. Он придерживался традиционного северного образа жизни - был охотником, 
рыбаком, звероводом, оленеводом. В конце І980-х гг. вынужден был пойти в политику - так хотя бы в какой-то мере можно было отстаивать права коренного населения. Вэлла был глубоким исследователем материальной и духовной культуры лесных ненцев, без отрыва от окружающей этнографической действительности работал научным сотрудником, создал музей под открытым небом. Наконец, он получил образование в Литературном институте имени А.М. Горького.

Юрий Вэлла - поэт столкновений, больших внутренних конфронтаций. Словесность стала для него, пожалуй, основной формой личностного сопротивления. Речь идет не только о неравном противостоянии нефтедобывающим корпорациям, поглощающим ненецкие и хантыйские просторы. Вэлла пытался бороться с реальностью лингвистической несправедливости, стремился сконструировать «иврит» диалекта лесных ненцев. Параллельно пробовал писать по-хантыйски, в итоге окончательно перешел на русский, сумев создать синкретическое художественное пространство диалога трех культур, литератур. Долгое время творчество Ю. Вэллы находилось как бы вне контекста принадлежности к какой-либо национальной традиции. Он словно оказался между народов, языков. Однако со временем все более очевидными и закономерными стали внутренние связи его художественного дискурса именно с ненецкой литературой. Изначальная территориальная, языковая удаленность от ойкумены тундровых ненцев была преодолена самим поэтом, ориентированным на тексты ненецких писателей-классиков (В. Ледков, Л. Ненянг). Ю. Вэлла, будучи этническим ненцем, не мог не ассоциировать свои произведения с ненецкой литературной традицией, пусть и представляющей другую вариацию языка.

Творческое наследие Ю. Вэллы только в последние годы постепенно становится объектом научного рассмотрения. Его тексты исследуются не только литературоведами [2; 13; I5; 16; 22], но и этнологами [I7; 19]. Основные книги Вэллы вышли еще при жизни автора (это и сборники стихов, прозы [3; 4; 6; го], и научно-популярные работы [7; 8; 9]). Очевидна необходимость многотиражных новых систематизирующих изданий, отражающих в наиболее полном формате сумму произведений поэта. Остались рукописи, неопубликованные материалы, также претендующие на отдельное издание. На сегодняшний день отсутствуют монографические труды, в которых бы осмысливался феномен художественного мира Вэллы. 
Своеобразие поэтической системы Юрия Вэллы определяется рядом особенностей, которые мы хотели бы обозначить непосредственно перед аналитическим прочтением конкретных текстов. Ю. Вэлла отдает предпочтение форме верлибра. Однако среди его стихотворений имеют место и рифмованные, которые, как правило, жанрово маркированы (например, песни). Стихотворные произведения Ю. Вэллы отличаются достаточно большими текстовыми объемами, тексты-миниатюры встречаются редко. Отчасти это специфическое явление обусловлено ярко выраженной сюжетностью стихов: в них развернуто представлены жизненные ситуации, истории переживания, картины ненецкого мироустройства, описываются глобальные изменения экологической миросистемы ненцев. Для творчества Ю. Вэллы характерна выверенность, продуманность художественного пространства, его книги четко структурированы, отчетливо прослеживается проблемно-тематическая классификация текстов, большинство стихотворений озаглавлены. Поэтической модели Вэллы свойственна высокая степень циклообразования, чаще встречается форма триптиха. Многие стихотворения Ю. Вэллы имеют эпиграфы, преимущественно состоящие из отрывков беседы ненцев или ненецких пословиц, предваряющих лирических сюжет наблюдений.

Поэзия Юрия Вэллы в значительной степени автобиографична. Автор творчески откликается на события, которые происходят непосредственно с ним, с его ближним кругом (семья - род - народ). Границы его художественного мира, как правило, совпадают с пространством малой родины, с континуумом личного опыта.

Книги Юрия Вэллы (речь идет о художественных изданиях) лишь с оговорками можно назвать стихотворными сборниками. Поэтические тексты «разбиваются» прозаическими вставками, ненецкий писатель обращается к разным жанровым форматам. Фрагменты прозаического письма (короткие истории) тематически, сюжетно корреспондируют с поэтическим блоком. Стихотворные сборники Юрия Вэллы, выходившие в 1990-200о-е гг., имеют общий текстовой «каркас». Автор добавляет к ранее изданным стихам несколько новых, при этом расширяет языковое пространство каждой последующей книги, включает в них переводы на другие языки (например, на французский). Поэт каждый раз по-новому размещает тексты в структуре издания, собирает прежде разрозненные 
стихи в циклы, тем самым создавая новый художественный контекст их бытования.

Отдельной ремарки заслуживает качество русского языка стихов Юрия Вэллы. В его текстах нет стилистического напряжения неродного слова, выраженных грамматических неправильностей, синтаксического «коллапса». Его русский, слегка «разбавленный» терминами ненецкой духовной и материальной культуры, кажется абсолютно естественной формой творческого самовыражения. Вэлла гармонично представляет по-русски свой сложный, символически и ситуативно насыщенный ненецкий мир. Ю. Вэлле удалось избежать «языковой ломки», преследующей многих писателей-этнофоров, рискнувших творить по-русски.

Главная тема творчества Юрия Вэллы - тема случившейся экологической катастрофы. Северные территории Западной Сибири, места исконного проживания лесных ненцев, хантов и манси, на протяжении десятилетий осваиваются нефтедобытчиками. Вырубались леса, истреблялись животные, природе был нанесен невосполнимый ущерб. Прежде обширные природно-культурные пространства сузились до островков хрупкой стабильности. Привычный уклад жизни коренных народов оказался под угрозой, обострились социальные проблемы, ассимиляция приобрела огромные масштабы, процесс утраты миноритарных языков региона, кажется, уже невозможно остановить. Юрий Вэлла, многие другие национальные писатели Югры (например, хантыйский прозаик Еремей Айпин) восприняли происходящее как личный апокалипсис. Примечательно, что экологическая тематика в произведениях большинства ненецких писателей отсутствует или обозначена факультативно. В случае с Ю. Вэллой один из факторов радикализации этноэкологической проблематики - месторасположение его стойбища, земель его рода. Окрестности Нижневартовска, Сургута, Ханты-Мансийска пострадали особенно сильно. Здесь регулярно случались техногенные аварии, которые обычно замалчивались, скрывались от общественности. Поэтическое освещение, осмысление катаклизмов Вэллой в некотором роде нужно прочитывать как опыт коллективного духовного сопротивления, как попытку создания особого дискурса этнической травмированности.

Одно из наиболее ярких, пронзительных, глубоко пессимистичных стихотворений ненецкого поэта - «Мутация». Текст открывается фраг- 
ментом разговора деда и внука, в котором сообщается о жутковатом улове (в родном озере поймали щуку с четырьмя ноздрями, рогами). Автор не ограничивается описанием, придумыванием внешних мутаций (предъявляет читателю образ своего мутированного деда), он предполагает наличие мутаций внутренних, ментально-экзистенциальных, деформирующих сознание и поведение человека. Вэлла почти всегда придает своим финальным строкам выраженное философское звучание: «Люди! / Может, такая мутация / В нас уже началась? / Или пока, слава богу, нет еще / Двоеголовых и троеруких? / Но, может, / Для нас незаметно / В нашей жизни уже наступила / Мутация наших поступков, / Мутация отношений, / Мутация наших чувств?» [Іо, с. I35].

Ю. Вэлла часто выдумывает колоритных персонажей, говорит от их имени, подбирает оригинальную жанровую конструкцию. Такая стратегия текстопорождения явлена в произведении «Причитания Старого Усти». Это причитания человека, не мыслящего себя вне своего этнокультурного ландшафта, природного универсума. Сталкиваясь с ужасающей реальностью современной промышленной цивилизации, герой испытывает постоянную физическую и душевную боль. Его тело и тяжело раненная индустриальными вторжениями природа родного края образуют единый живой организм. Внутренние терзания, сопротивление Усти, мучительное ощущение текущей ситуации получают языковое выражение в виде частицы «не»: уже невозможно что-либо изменить и невозможно принять происходящее. На наш взгляд, не случайна внутритекстовая актуализация «инфинитивного ресурса»: не уснуть, не проснуться, некуда деться, некогда оглянуться, некогда задуматься. Инфинитивное письмо в структуре текстового целого нередко указывает на особый риторический статус, свидетельствует о высоком уровне экспрессивности высказывания. Уничтожение экосистемы для лирического «Я» равноценно самоуничтожению. Поэт в рассматриваемом стихотворении оперирует категорией «род», которая в его творчестве являет собой многогранную смысловую синкрету. Род у Ю. Вэллы - особое этническое, природное, духовно-ценностное измерение. Тундра, тайга, ягель, деревья выступают как образные заместители ушедших из жизни бабушки, дедушки. Одним из говорящих рефренов текста становится глагольная форма «стонет», несущая открытый психосемантический посыл. В художественной ткани стихотворения задействованы цветовые символы, также 
характеризующие реальность этноса, бытие этнофора: «Олений мой род, / Теплую грудь / Пытаясь росой и дождями отмыть / От черной смертельной боли, / Стонет, / Стонет сквозь ноздри, / Едкою массой залитые, / Стонет глазами, / Где вместо слез - / Нефтяные разливы» [Іо, с. I49].

«Экологические» стихотворения в творчестве Ю. Вэллы особенно объемны. По-видимому, поэт хочет многое в них вместить, показать, привести разные художественные аргументы. В основе этих текстов - повторение определенных мотивов, образов, ситуаций. Одна из заметных деталей лирики ненецкого автора - обилие вопросительных знаков, вопросительных контекстов. Лирическое «Я» постоянно находится в режиме вопросительности. Произведение «Отнята земля - отнята душа» начинается и заканчивается вопросами, ответы на которые очевидны и сложны одновременно: «Где тропа, / По которой кочевал мой род? / Где урочище, что зверьем их кормило? / Где река, / Из которой поили детей? / Что с их небом, / Которому не только молились?» [4, с. 7].

В стихотворении постулируется мотив потери древнего ненецкого мира, своих корней, обыкновений. Этот мир ушел вместе с поколением бабушек / дедушек, его уже не вернуть, не возродить. Моделируется картина того, как было раньше, приводятся принятые в системе этноса модели, нормы повседневного отношения к природе, которые перестали работать, соблюдаться. В произведении фигурируют колористические эпитеты (белый месяи, белое солнце), символизирующие сакральный статус небесных светил.

Взаимосвязи природы и человека в представлении Ю. Вэллы глубинны. Их разрыв всегда чрезвычайно болезненный, несправедливый. В произведении «Заброшенный лабаз» обыгрывается мотив одиночества природы, которая остро переживает длительное отсутствие общения с людьми: «Тропинка заросла. / Уже лет двадцать / Хозяин на упряжке не был здесь. / Забыл свой лабаз? / Сам сгинул? / Или покинул родину свою? / Молчит сурово бор, / Заросший сосняком... / Молчит ручей соседний / С просохшим дном...» [4, с. І3]. В данном случае речь идет и о «разлуке» природы и этноса.

В стихах Ю. Вэллы хорошо выписан образ врага. Поэт редко изображает в этой ипостаси людей. Он на первый план выводит машины: «Здесь росла береза... / Бульдозер вырвал ее с корнями / И гусеницами стальными в 
липкую грязь вмолол...» [4, с. І2]; «Отнята земля / И брошена на растерзание / Под стальные гусеницы твои. / А проголодавшийся экскаватор, / Лязгая неистово, / Уже вынимает внутренности...» [4, с. 7]. Враги, вредители - это и «размытое» множественное число, отсутствие какой-либо персонификации: «О, тайга! - / Нет тайги - ее вырубили, / О, родная земля! - / Не осталось земли - / Ее превратили в сплошные дороги, / Ее превратили в сплошные карьеры, / Ее превратили в сплошные окраины городов» [4, с. 3I].

Особое место в поэтическом отображении природной катастрофы Югры занимает образ нефти. Нефть становится своеобразной «мертвой водой», она замещает собой живую воду сибирских рек: «Не выпита река, / А залита нефтью, / Не осушена река, / А заканчивается по притоку в час / Каждый день / Вот уже сотню месяцев / В нефтяные пласты...» [4, с. 8]; «По Ватьёгану плывет / Нефть, / Нефть, / Нефть. / Лодку, сети и весло / Пропитала нефть. / Щуку вспорешь - / Нож в нефти» [го, с. І33].

Среди основных человеческих персонажей поэзии Юрия Вэллы дедушки и бабушки. Они носители традиционной культуры, хранители рода, для них существует только один ненецкий мир с его еще не разоренной природой, живым, богатым языком. Дедушки и бабушки - постоянные герои экологических стихотворений. Это и реальные люди, столкнувшиеся с неразрешимыми проблемами глобального индустриального наступления, и одновременно добрые духи, посылающие сигналы тревоги своим потомкам. Яркий пример стихотворений данного типа - «Песня бабушки Ненги». Песня - один из ключевых жанров не только ненецкого, хантыйского фольклора, но и поэтической системы Ю. Вэллы. Бабушка Ненги шьет обувь и поет песню, в которой как бы проступают сюжеты будущего, предвидятся события жизни повзрослевшего внука. В тексте реализована заклинательная функция, в качестве этнического маркера используется ненецкое междометие: «Вот сошью кисы я внуку. / Нгадьеей-нго! / Чтоб не мерз в мороз и вьюгу. / Нгадьеей-нго! / А когда пойдет за зверем / Далеко, / Чтобы лыжи не скрипели. / Нгадьеей-нго! / Будет он пасти оленей. / Нгадьеей-нго! / Из реки добудет нельму. / Нгадьеей-нго!» [Іо, с. 27].

С большой нежностью, художественной достоверностью создан образ старой ненки Ымчи. Она беспокоится о сыне, находящемся в далеких краях, искренне не понимает, для чего людям нужно покидать отчий дом, жить по другим правилам, принимать обыкновения чужих. Одна из деталей 
лирического портрета - ненецкие звуковые рефрены: «Маленький мой, / Разве для тебя / Нет улова в родной реке? / Маленький мой, / Разве в нашем стаде / Нет олененка для твоего тынзяна? / Маленький мой, / Отчего ты сегодня не со мной? / Ёх-хо-хо-хов! / Что-то тревожно твое письмо. / Ёх-хо-хо-хов!» [Іо, с. 33].

Ключевой символ художественного мира Юрия Вэллы - образ неба. Ему приписываются антропоморфные свойства. Оно взаимодействует с лирическим героем, отвечает на его реплики, чувствует настроение, отвечает на эмоциональные порывы. Очень часто лексема «небо» употребляется с притяжательным местоимением «мой», подчеркивается особая метафизическая сопряженность неба и человека. «Свое» небо - это прежде всего небо малой родины: «Говорю тебе: “Здравствуй!” / И небо мое / Следом за мной / Тысячу раз повторяет: / “Здравствуй!” / Хочется крикнуть: “Люблю!” / И небо мое ждет, / Чтоб следом за мной / Тысячу раз повторить этот возглас...» [4, с. 23]. Небо в стихах Вэллы может быть и чужим, безучастным, отстраненным, неожиданно равнодушным по отношению к происходящим в жизни лирического «Я» событиям. Небо ревностно относится к перемещениям героя, опасается его существенных внутренних изменений после встречи с чужими землями: «И вот / Я снова возвращаюсь / С пляжного лета / На тундровый простор. / Как долго здесь я не был! / В глаза мои со всех сторон / Испытующе глядит / Доверчивое небо. / И чувствую, / Оно меня спросить желает: / - Не стал ли и ты / Серым / Средь серых людей? / Вернулся ли прежним - / Белым?» [4, с. 39].

Наряду с образом неба одним из излюбленных лирических символов Юрия Вэллы является дождь. Это несколько нетипичный выбор для ненецкого поэта: главным атмосферно-символическим явлением северного художественного ландшафта обычно становится снег. Однако Вэлла изменяет этой традиции, по-видимому, не столько в силу несколько иного географического положения своей малой родины (южные границы ненецких этнических территорий), сколько по причине лирико-семантической многоплановости дождя. В некотором роде, актуализируя изобразительные коды и психологические подтексты этого символа, поэт вступает в диалог с традициями «большой» словесности. Осенний дождь в одноименном стихотворении [Іо, с. I4] оказывается объектом созерцания. Лирический герой наблюдает за ним, описывает, как дождь меняет картинку за окном. 
Размываются границы внешнего мира, но при этом визуально обостряются отдельные составляющие панорамы. В тексте дождь сравнивается с юрким червем, проникшим глубоко в землю. Он активен, ему хочется попасть в человеческое пространство, он ассоциируется с ненецким шаманом.

В стихотворном корпусе Юрия Вэллы заметное место занимают урбанистические нарративы. Любопытно, что поэт отказывается от изображения городов, которые находятся рядом с его родовыми землями. Основное городское пространство у Вэллы образуют московские топосы. Художественное упоминание столицы, по-видимому, имеет автобиографические корни (поэт учился в Литературном институте им. А.М. Горького). И вместе с тем Москва для Ю. Вэллы абсолютно чужая. Здесь люди живут другими заботами, преследуют другие цели. К урбанистическим стихам относится текст «На троллейбусной остановке». Лирическое «Я», просматривая объявления, испытывает чувство недоумения, внутреннее несогласие. Картина мира, потребности и ценности москвичей кажутся субъекту-этнофору ненастоящими, лишенными подлинного смысла: «Стою возле будки / На остановке, / Читаю обрывки бумажных фраз: / “Меняется...”, / “Срочно меняем...”, / “Разъезд...” / “...трехкомнатную, / С балконом на юг. / К концу пятилетки...” / И подумалось вдруг: / Неужели когда-то / На развилке оленьих дорог / И мои сородичи / Станут взывать: / “Семья развалилась, / Меняется чум...”, / “Мой муж алкоголик, / Меняю семью...”, / “Поссорились с зятем, / Меняется род...” [Іо, с. 66-67]. Отраженная в приведенных строках советская действительность уже «предсказывает» скорые разъезды, переезды, глобальные изменения, исчезновения. Город у Вэллы рифмуется с одиночеством, ассоциируется с молчанием, он угнетает, давит, лирическому герою здесь неуютно, холодно.

Города у Юрия Вэллы подразделяются на настоящие и ненастоящие, временные. Об урбанистическом топосе второго типа стихотворение «Временный город». Когалым Лор, построенный для нефтяников, - локус-призрак, воплощающий ложные материальные ценности и духовную ограниченность живущих здесь людей. Хантыйская этимология искусственного города глубоко символична: это мертвое место, земля умерших. Не знающий языков и древних имен человек со стертым этническим обликом возводит жилище там, где нельзя. Любопытно художественное представление коренных народов. Ненцы, ханты с некоторым злорадством наблюда- 
ют за обыкновениями приезжих-чужих: «Пышен блеск нефтяных рублей. / Чумы стиснуты поодаль. / Хант смеется в оскал бубна. / Ненец в ресницы ухмыляется - / На мертвом месте / Мертвый город / Мертвым будущим бахваляется. / Временные люди / Во временном баре / Временное пиво / С жадностью отхлебывают. / Временное столетие / Над их плечами / Временные минуты / В часах отстукивает...» [1о, с. 136].

В целом, в поэзии Юрия Вэллы город представляет собой визуально не активированный хронотоп. Лирический субъект делится с реципиентом набором ситуаций, своими внутренними переживаниями, но не зрительными впечатлениями. Урбанистические тексты ненецкого поэта оказываются психологически концентрированными, пессимистическими, отличаются скупой образностью, доминированием внутреннего над внешним. Изображение города в стихотворениях Ю. Вэллы корреспондирует со стратегиями его негативного художественного представления, описания, сложившимися в других литературах народов России.

Интересный в аналитическом плане жанровый эксперимент Ю. Вэллы - поэтический диалог с русской югорской поэтессой Татьяной Юргенсон, получивший название «Охота на лебедей» [II]. Это перекличка стихотворений, взаимодействие двух разных стилей, иногда «устремленных» навстречу друг другу. Входящие в данную жанровую модификацию тексты на первый взгляд тематически разноплановые. Вместе с тем Вэлла предлагает творческому собеседнику набор своих инвариантных лирических мотивов, предлагает разделить его мировидение. Соавтор включается в эту игру, пытается настроить оптику ненецкого этнофора. Реплики, реакции лирического «Я» Т. Юргенсон принадлежат человеку города, осторожно, с интересом познающему миры природы. «Охота на лебедей» - развивающаяся цепочка сюжетов и форм: диалог начинается с загадки, продолжается текстами-наблюдениями за жизнью рек, текстами-мечтами о полете, парении, потом происходит переключение на философско-социальную проблематику. При этом именно стихи Юрия Вэллы привычно транслируют состояния значительного эмоционального напряжения, образы опасной современности. Уже невозможно просто так спрятаться в свой мир, укрыться от внешних неблагоприятных, расшатывающих этническое мироздание условий, рамок бытия.

Художественно значимый пласт поэзии Юрия Вэллы составляет любовная лирика. Любовь в его стихотворениях полна романтизма, самопо- 
жертвования, вдохновения, недосказанности, печали. Отношения между мужчиной и женщиной в традиционном ненецком обществе были регламентированы народными предписаниями. Любить человека нужно правильно, оглядываясь на обычаи. При этом глубокое знание «кодекса любви» предков не мешает автору создавать собственную реальность чувства, свою этику. В тексте «Иду на охоту» [4, с. 20] символическое определение любви - эхо, сопровождающее лирического героя повсюду. Метафорическое эхо Ю. Вэллы - явление многогранное, не только акустическое, но и визуальное, воображаемое, эмоциональное, тактильное. Вновь настоящее большого чувства соотнесено с прошлым.

Там, где возникает сильное психологическое напряжение, у Ю. Вэллы начинают говорить, оживать вещи. Предметный код актуализирован в произведении «Опустел мой дом» [4, с. 26]. Это одно из наиболее проникновенных стихотворений ненецкого поэта. С лирическим героем печаль расставания делят объекты материального мира - крыльцо, стол, стул, дверь, окно. Вещи, дом выступают как свидетели общего, единого прошлого «Я» и «Ты». Символы двери, окна подчеркивают ситуацию пограничья, усиливают ощущение одиночества. В стихотворении «Вроде всё» [4, с. 26] «оживают» дверь и порог, в традиционной культуре символизирующие границу, переход из одного состояния в другое. Данная мифологическая функция образов срабатывает, лирический субъект, выделяя указанные пространственно-предметные реалии, предчувствует их сакральное предназначение. Перешагивая через порог, захлопнув дверь, он выходит из отношений. Любовную лирику Вэллы отличает деликатность. Поэт уклоняется от художественной передачи неудобных подробностей распадающихся отношений. Его привлекают, вдохновляют высокие переживания, послевкусие разлуки. Возлюбленная лирического «Я» загадочна, закрыта от читателя.

За несколько лет до смерти Ю. Вэлла побывал в США. Путешествие, одним из организаторов которого был известный российский филолог, переводчик, профессор МГУ А.В. Ващенко, «переросло» в серию стихотворений и путевых заметок. Этот срез художественного наследия Вэллы, как и многие его поздние тексты, полностью не опубликован. Отдельные фрагменты были размещены в Интернете. Поэта интересуют прежде всего бытие и быт американских индейцев, с которыми он ассоциирует ненцев, находит немало общего в их исторической судьбе и повседневности. 
Центральным образом американских стихов становится река Рио-Гранде. Представленное в тексте «ритуальное общение» лирического героя с рекой восходит к фольклорно-мифологическим представлениям ненецкого этноса, сакрализующим воду, реки. Рио-Гранде для него - одно из воплощений «большой живой воды» человечества, духовной памяти предков. «Я»-субъект, невзирая на огромное расстояние между Америкой и Сибирью, ощущает ментальную близость, родство двух исчезающих народов. Однако эта авторская сентенция прочитывается между строк, не эксплицируется. Для Вэллы значительно важнее проявить внутреннее единство со своим этносом, который в лице отдельно взятого этнофора постигает Америку:

Я опустил в реку монетку за себя, за то, что осмелился топтать здешнюю землю, корни растений, за то, что осмелился пить здешнюю воду, вдыхать здешний воздух.

Я опустил в реку монетку за своих товарищей-родственников, которые здесь находятся вместе со мной в Америке, и здесь останутся наши следы, наше влияние.

Я опустил в реку монетку за близких, которые остались дома на Тюйтяхе и в Варьёгане, потому что я все время чувствую, что и они со мной здесь, что мысленно и они вместе со мной топчут здешнюю траву, опускают руки в воду здешней реки и вдыхают высокогорный воздух здешней земли. Я чувствую себя проводником между разными континентами. Я чувствую себя проводником между полюсами нашей Планеты. Я гляжу на здешнее солнце, но чувствую тепло солнца моей тундры. Я моюсь прохладой здешней реки Рио-Гранде, но чувствую в этот миг прохладу Тюйтяхи и Оби.

Спасибо вам, Боги, за то, что я есть, за то, что я чувствую окружающий мир, за то, что я способен еще любить Жизнь! [г2]

Вэлла - поэт, живший и писавший наедине со всеми. Невзирая на регулярные апелляции к коллективному (осознанному коллективно-родовому началу, неосознанному советскому), он был абсолютным раненым одиночеством, северным индивидуалистом. Отсюда - очень развитое чувство ответственности, вдохновляющее и разрушительное одновременно. Некоторая наивность поэтической картины мира Юрия Вэллы, по-видимо- 
му, осознанная художественная стратегия, воздействующая на реципиента и повышающая степень драматичности восприятия текстов. В некотором смысле Ю. Вэлла - поэт-артист, понимающий, чего от него ждут читатели и критики, знающий, на какие «кнопки» словесности нужно нажимать. Традиционная культура, этноментальные особенности коммуникации лирических субъектов «погружены» в сложный синтетический дискурс современного верлибра. Вэлла - поэт взаимодействия, взаимоналожения различных культурных форм, разных семиотических систем. Очевидно, что творчество Юрия Вэллы - один из редких художественно-эстетических «прорывов» младописьменной литературы на рубеже XX-XXI столетий.

Примеры «малых» литератур отсылают к большим проблемам народов Крайнего Севера, которые в советские годы были вырваны из привычной колеи, «приручены», переселены на «рельсы» социализма, соцреализма. Мировидение, мирочувствование - сложнейшие, тончайшие категории бытия, которые невозможно в одночасье отменить, перенастроить. История, реальность развития младописьменных литературно-художественных традиций (в данном случае - ненецкой) - предмет не только литературоведения, но и этнографии, философии. Речь идет о глобальных проблемах обустройства жизни, о больших цивилизационных «сломах», об ответственности больших народов перед малочисленными, прирученными и в значительной степени брошенными, оставленными наедине с жестоким и прагматичным, деэтнизирующим индустриальным миром.

\section{Список литературы}

I Аминева B.P. Сопоставительное изучение русской и татарской литератур. Казань: Редакционно-издат. центр «Школа», 20I7. 264 с.

2 Арзамазов А.А. Белые крики в черной тишине: этнопоэтический мир Юрия Вэллы // Эскизы: варианты, интертексты, стратегии, тактики, семиосферы, стиходвижение. Ижевск: Инвожо, 2005. С. 89-93.

3 Вэлла Ю. Белые крики: Книга о вечном. Сургут: Северный дом, I996. І68 c.

4 Вэлла Ю. Вести из стойбища. Радужный: Гор. тип., І99г. 48 с.

5 Вэлла Ю. Земля любви: Диалоги. Ханты-Мансийск: Принт-Класс, 20II. 208 с.

6 Вэлла Ю. Поговори со мной: книга для ненецкого студента и для того, кто хотел бы послушать ненецкую душу. СПб.: Миралл, 2007. 152 с. 
Вэлла Ю. Река Аган со притоками. Опыт топонимического словаря. Бассейн реки Аган. Ханты-Мансийск: ИИЦ ЮГУ, 2ого. Ч. І. І46 с.

Вэлла Ю. Река Аган со притоками. Опыт топонимического словаря. Бассейн реки Аган. Ханты-Мансийск: Доминус, 20I2. Ч. 2. І86 с.

Вэлла Ю. Река Аган со притоками. Опыт топонимического словаря. Бассейн реки Аган. Ханты-Мансийск: Юграфика, 2012. Ч. 3. І50 с.

Вэлла Ю. Триптихи. Ханты-Мансийск: Полиграфист, 200I. I68 с.

Вэлла Ю., Юргенсон Т. Охота на лебедей: Диалог. Ханты-Мансийск: Полиграфист, 200I. IO C.

Дым Ю. Америка Юрия Веллы. URL: https://www.proza.ru (дата обращения: I5.II.2019).

I3 Жулева А.С. Юрий Вэлла: литератор, просветитель, оленевод // Вопросы истории и культуры северных стран и территорий. 20I7. № 3 (35). С. І8-27.

I4 Кучукова З.А., Хараева Л.Ф. Гендер и этногендер (на материале кабардинской женской прозы). Нальчик: Издат. тип. «Принт Центр», 20I8. 192 с. Лагунова О.К. Поэтика книги Ю.К. Вэллы «Белые крики» // Вестник Тюменского государственного университета. 2003. № 4. С. 45-6I.

Лагунова О.К. Феномен творчества русскоязычных писателей ненцев и хантов последней трети XX века (Е. Айпин, Ю. Вэлла, А. Неркаги). Тюмень: Изд-во Тюменского гос. ун-та, 2007. 258 с.

I7 Новикова Н.И. Модель многокультурности Юрия Вэллы // Вестник угроведения. 20I8. № 2. С. 376-384.

I8 Родионов В.Г. Чувашское сравнительное литературоведение: теория и практика. Чебоксары: Новое время, 20I7. 92 с.

I9 Сподина В.И. Представление о пространстве в традиционном мировоззрении лесных ненцев. Новосибирск: Издат. центр «Агро»; издат. группа «Солярис»; «ЦЭРИС», 200I. І24 c. Султанов К.К. От Дома к Миру. Этнонациональная идентичность в литературе и межкультурный диалог. М.: Наука, 2007. 302 с. Султанов К.К. Угол преломления. Литература и идентичность: коммуникативный аспект. М.: ИМЛИ РАН, 2ОI9. 352 с.

22 Тулуз Е. Две ветви одного дерева / пер. с франц. Марии Ерёменко // Мир Севера. 2000. № 5. С. $70^{-} 73$.

23 Хазанкович Ю.Г. Фольклорно-эпические традиции в прозе малочисленных народов Севера. Новосибирск: Изд-во СО РАН, 2009. ІзІ с. 


\section{References}

Amineva V.R. Sopostavitel'noe izuchenie russkoi i tatarskoi literatur [Comparative study of Russian and Tatar literature]. Kazan, Redaktsionno-izdatel'skii tsentr "Shkola” Publ., 20I7. 264 p. (In Russ.)

Arzamazov A.A. Belye kriki v chernoi tishine: etnopoeticheskii mir Iuriia Velly [White screams in black silence: ethno-poetic world of Yuri Vella]. In: Eskizy: varianty, interteksty, strategii, taktiki, semiosfery, stikhodvizhenie [Sketches: options, intertexts, strategies, tactics, semiosphere, and poetry movement]. Izhevsk, Invozho Publ., 2005, pp. 89-93. (In Russ.)

Vella Iu. Belye kriki: Kniga o vechnom [White screams: A book about the eternal]. Surgut, Severnyi dom Publ., I996. I68 p. (In Russ.)

Vella Iu. Vesti iz stoibishcha [News from the nomad camp]. Raduzhny, Gorodskaia tipografiia Publ., I99I. 48 p. (In Russ.)

Vella Iu. Zemlia liubvi: Dialogi [Land of love: Dialogues]. Khanty-Mansiysk, Print-Klass Publ., 20II. 208 p. (In Russ.)

Vella Iu. Pogovori so mnoi: kniga dlia nenetskogo studenta $i$ dlia togo, kto khotel by poslushat' nenetskuiu dushu [Talk to me: a book for a Nenets student and for one who would like to listen to the Nenets soul]. St. Petersburg, Mirall Publ., 2007. I52 p. (In Russ.)

Vella Iu. Reka Agan so pritokami. Opyt toponimicheskogo slovaria. Bassein reki Agan [Agan River with tributaries. Toponymic dictionary experience. Agan river basin]. Khanty-Mansiysk, IITs IuGU Publ., 20IO. Part I. I46 p. (In Russ.)

Vella Iu. Reka Agan so pritokami. Opyt toponimicheskogo slovaria. Bassein reki Agan [Agan River with tributaries. Toponymic dictionary experience. Agan river basin]. Khanty-Mansiysk, Dominus Publ., 20I2. Part 2. I86 p. (In Russ.)

Vella Iu. Reka Agan so pritokami. Opyt toponimicheskogo slovaria. Bassein reki Agan [Agan River with tributaries. Toponymic dictionary experience. Agan river basin]. Khanty-Mansiysk, Iugrafika Publ., 2012. Part 3. I50 p. (In Russ.)

Vella Iu. Triptikhi [Triptychs]. Khanty-Mansiysk, Poligrafist Publ., 200I. I68 p. (In Russ., in Nenets, in French) Vella Iu., Iurgenson T. Okhota na lebedei: Dialog [Swan hunting: Dialogues]. KhantyMansiisk, Poligrafist Publ., 200I. Io p. (In Russ.) Dym Iu. Amerika Iuriia Velly [Yuri Vella's America]. Available at: https://www.proza.ru (Accessed I5 November 20I9). (In Russ.)

3 Zhuleva A.S. Iurii Vella: literator, prosvetitel', olenevod [Yuri Vella: writer, enlightener, and reindeer herder]. Voprosy istorii i kul'tury severnykh stran i territorii, 20I7, no 3 (35), pp. I8-27. (In Russ.)

Kuchukova Z.A., Kharaeva L.F. Gender i etnogender (na materiale kabardinskoi zhenskoi prozy) [Gender and ethnogender (based on Kabardian female prose)]. Nalchik, Izdatel'skaia tipografiia “Print Tsentr” Publ., 20I8. I92 p. (In Russ.) 
I5 Lagunova O.K. Poetika knigi Iu.K. Velly "Belye kriki” [Poetics of the book by Y.C. Vella “White screams”]. Vestnik Tiumenskogo gosudarstvennogo universiteta, 2003, no 4, pp. 45-6I. (In Russ.)

I6 Lagunova O.K. Fenomen tvorchestva russkoiazychnykh pisatelei nentsev $i$ khantov poslednei treti XX veka (E. Aipin, Iu. Vella, A. Nerkagi) [The phenomenon of Russophone Nenets and Khanty writers of the last third of the $20^{\text {th }}$ century (E. Aipin, J. Vella, A. Nerkagi)]. Tyumen, Izdatel'stvo Tiumenskogo gosudarstvennogo universiteta Publ., 2007. 258 p. (In Russ.)

I7 Novikova N.I. Model' mnogokul'turnosti Iuriia Velly [The multicultural model of Yuri Vella]. Vestnik ugrovedeniia, 2018, no 2, pp. 376-384. (In Russ.)

I8 Rodionov V.G. Chuvashskoe sravnitel'noe literaturovedenie: teoriia i praktika [Chuvash comparative literature: theory and practice]. Cheboksary, Novoe vremia Publ., 2017. 92 p. (In Russ.)

I9 Spodina V.I. Predstavlenie o prostranstve v traditsionnom mirovozzrenii lesnykh nentsev [The idea of space in the traditional worldview of the forest Nenets]. Novosibirsk, Izdatel'skii tsentr “Agro” Publ., Izdatel'skaia gruppa “Soliaris” Publ., “TsERIS” Publ., 200I. I24 p. (In Russ.)

20 Sultanov K.K. Ot Doma k Miru. Etnonatsional'naia identichnost' v literature $i$ mezhkul'turnyi dialog [From home to the world. Ethnic identity in literature and intercultural dialogue]. Moscow, Nauka Publ., 2007. 302 p. (In Russ.) Sultanov K.K. Ugol prelomleniia. Literatura i identichnost': kommunikativnyi aspect [The angle of refraction. Literature and identity: communicative aspect]. Moscow, IWL RAS Publ., 2019. 352 p. (In Russ.)

22 Tuluz E. Dve vetvi odnogo dereva [Two branches of the same tree], transl. from French by Maria Eremenko. Mir Severa, 2000, no 5, pp. 70-73. (In Russ.)

23 Khazankovich Iu.G. Fol'klorno-epicheskie traditsii v proze malochislennykh narodov Severa [Folklore-epic traditions in the fiction of the indigenous small peoples of the North]. Novosibirsk, Izdatel'stvo SO RAN Publ., 2009. I3I p. (In Russ.) 